This is a self-archived version of an original article. This version may differ from the original in pagination and typographic details.

Author(s): Aula, Hannamari; Siltaoja, Marjo

Title: Praised from birth : social approval assets in the creation of a new university

Year: 2021

Version: Published version

Copyright: (c) 2021 the Authors

Rights: CC BY 4.0

Rights url: https://creativecommons.org/licenses/by/4.0/

Please cite the original version:

Aula, H., \& Siltaoja, M. (2021). Praised from birth : social approval assets in the creation of a new university. Baltic Journal of Management, 16(4), 638-657. https://doi.org/10.1108/bjm-042020-0103 


\title{
Praised from birth: social approval assets in the creation of a new university
}

\author{
Hannamari Aula \\ T-Media, Helsinki, Finland, and \\ Marjo Siltaoja \\ Jyvaskylan Yliopisto, Jyvaskyla, Finland
}

\begin{abstract}
Purpose - The authors explore how social approval assets, namely status and reputation, are used to legitimate and categorise a new national university. They argue that in the course of the legitimation process, status and reputation work as stakeholder-oriented value-creating benefits. The authors specifically analyse the discursive constructions and labels used in the process and how the process enables nationwide university reform.

Design/methodology/approach - The authors' longitudinal case study utilises critical discourse analysis and analyses media and policy discourses regarding the birth of Aalto University.

Findings - The findings suggest that the legitimation of the new university was accomplished through the use of two distinct discourses: one on higher education and another on the market economy. These discourses not only sought to legitimise the new university as categorically different from existing Finnish universities, but also rationalised the merger using the expected reputation and status benefits that were claimed would accrue for supporters.

Practical implications - This study elaborates on the role of various social approval assets and labels in legitimation processes and explores how policy enforcement can take place in arenas that are not necessarily perceived as policymaking. For managers, it is crucial to understand how a chosen label (name) can result in both stakeholder support and resistance, and how important it is to anticipate the changes a label can invoke. Originality/value - The authors propose that the use of several labels regarding a new organisation is strategically beneficial to attracting multiple audiences who may hold conflicting interests in terms of what the organisation and its offerings should embody. They propose that even though status and reputation have traditionally been defined as possessions of an organisation, they should be further understood as concepts used to disseminate and justify the interests, norms, structures and values in a stakeholder network.
\end{abstract}

Keywords Reputation, Status, Higher education, Discourse

Paper type Research paper

\section{Introduction}

Status, legitimacy and reputation are valuable assets that organisations can use to attract or maintain social approval. These so-called social approval assets influence how stakeholders evaluate an organisation (Pfarrer et al., 2010), support it and exchange resources with it (Rindova and Fombrun, 1999) by providing cues about the organisation's expected current and future behaviour. However, new organisations or organisational forms that have not yet been established, or have existed for only a very short time, often lack these assets (Petkova, 2016), creating challenges for their future existence and resource flow.

Category studies have tackled this issue by showing how new organisations can seek strategic advantage by adopting labels and naming practices that signal the organisation's

(C) Hannamari Aula and Marjo Siltaoja. Published by Emerald Publishing Limited. This article is published under the Creative Commons Attribution (CC BY 4.0) licence. Anyone may reproduce, distribute, translate and create derivative works of this article (for both commercial and non-commercial purposes), subject to full attribution to the original publication and authors. The full terms of this licence

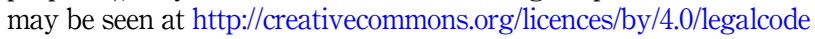

Received 3 June 2020 Revised 12 October 2020 10 January 2021 18 March 2021 Accepted 20 April 2021 
legitimacy and increase its valuation (Granqvist and Siltaoja, 2020; Negro et al., 2015), particularly among financiers and supporting (elite) actors (Rao et al., 2003). Furthermore, some names and labels are more important than others. Strategic naming can enhance audience attention, yet the use of familiar names is not itself sufficient; rather, "names imbued with known reputations serve as [a] symbolic device that enhances audience attention" (Zhao et al., 2013, p. 1747).

However, what remains scarcely examined in the literature is how emerging organisations that result from a merger seek to attract multiple audiences that have conflicting interests in terms of what the longstanding category of the organisation and its offerings should embody. We address this gap by building on the argument that when establishing a new organisation which is claimed to be different from the other representatives of that category, focal actors mobilise social approval assets in order to influence its legitimacy (see Hubbard et al., 2017). The role of media has been acknowledged as being particularly vital in such a value debate (Siltaoja and Vehkaperä, 2010; Siltaoja et al., 2020), and higher education offers an intriguing context as universities are increasingly thought of as competitive actors that need to position themselves strategically in a competitive academic field (Wedlin, 2008). Not only do these organisations try to respond to hybrid demands regarding the nature of academic science (Sauermann and Stephan, 2013), but they also compete for favourable assessments regarding their performance and categorise their products and themselves strategically using the labels of varying rankings (Kodeih et al., 2019; Siltaoja et al., 2019).

Our research question is how different labels and claims of stakeholder benefits are discursively constructed and used in the legitimation of a new higher education organisation. Utilising discourse analysis, an approach widely used to study legitimation and power struggles (Krejsler, 2006; Siltaoja and Vehkaperä, 2010; Siltaoja et al., 2020; Vaara et al., 2006), we examine the birth and legitimation of Aalto University in Finland. This unique merger required significant changes in state legislation and subsequently drove a major nationwide university reform in the country (Granqvist and Gustafsson, 2016). Our empirical data cover a longitudinal 5-year period (2005-2009); that is, before, during and after the merger of three universities in 2010 that resulted in Aalto University. We examine media texts, communication materials and public reports on the issue.

The findings suggest that the meaning of the new university was constructed using two distinct discourses: one on higher education and another on the market economy. These discourses mobilised two different names (labels) - "innovation university" and "top university" - positioning the new university as part of a group of elite international universities and differentiating it from existing Finnish universities. In addition, it was claimed that the establishment of the new university would result in status and reputation benefits for stakeholders. The establishment process of the new university further legitimated a hybrid Mode 2 university model in Finland, dedicated to research, yet simultaneously extending university activities across organisational and institutional boundaries (Styhre and Lind, 2010).

This study makes two main contributions. First, we contribute to the nascent literature on social approval assets from discursive and critical perspectives. We suggest that social judgement assets have been traditionally defined as the possession of an organisation (e.g. Deephouse and Carter, 2005; Deephouse and Suchman, 2008; Fombrun and Van Riel, 1997; Washington and Zajac, 2005), and we conceptualise them as interest and power games used to disseminate and justify new interests, norms, structures and values in a stakeholder network. Second, we contribute to the literature on strategic categorisation and the use of labels (Kodeih et al., 2019; Negro et al., 2015; Pontikes and Kim, 2017). This literature is dominated by the assumption that strategic categorisation is a managerially driven act that the organisation is supposed to signal. However, we argue that the strategic categorisation process of a new organisation evolves over time and is driven by multiple stakeholders and 
their interests embedded in particular labels (names). The study further offers practical value for managers by highlighting the importance of naming and labelling processes, and by pointing out how labels are not mere names and signals but can connect to ideological motivations and play a role in category transformations.

We first conceptualise social approval assets from a discursive perspective. We then explore the recent changes in the higher education sector and exemplify why legitimacy, status and reputation have become so vital in the field. This section is followed by the case description, analysis and findings. In the discussion section, we elaborate on our theoretical and practical contributions.

\section{Setting the scene: legitimacy, reputation and status as discursive assets}

Legitimacy, reputation and status are all assets of social valuation, concepts that result from social judgement processes of entities such as organisations. Much literature has sought to conceptually define and separate these concepts, with the underlying claim that once an organisation is thought to possess them they become social assets for its continuity and existence (e.g. Deephouse and Carter, 2005; Deephouse and Suchman, 2008; Fombrun and Van Riel, 1997; Washington and Zajac, 2005). Recent foci in the literature include the social processes related to judgement formation and how these assets can be used as frames to influence audiences' interpretations of information about new organisations (Hubbard et al., 2017). We use Bitektine's (2011) conceptualisation to distinguish between status, legitimacy, and reputation and explain how these concepts can be used and mobilised as frames by focusing on the discursive aspects of social assets (e.g. Lähdesmäki and Siltaoja, 2010; Siltaoja and Vehkaperä, 2010; Suddaby and Greenwood, 2005; Vaara and Monin, 2010; Vaara et al., 2006).

Bitektine (2011, pp. 162-163) suggested that as a social asset, socio-political legitimacy derives from the evaluation of whether the organisation is beneficial for the society in which the evaluator is embedded. The stakeholder renders a judgement regarding whether the organisation and its form, processes, and outcomes are socially acceptable and thus should be encouraged (or at least tolerated), or are unacceptable and thus the organisation should be sanctioned, dismantled, or forced to change the way it operates. The discursive framing can then seek to communicate issues that would be beneficial and acceptable from the evaluator's standpoint, increasing the salience of the organisation and its activities. Although this process is somewhat complex for new organisations to achieve, drawing on value claims that other existing organisations are perceived as being unable to provide is an important means of achieving this purpose. These claims are then likely to build on causes explaining how the activities of a new organisation have certain expected effects. For example, framing the organisation as a response to a growing need can generate such effects (Golant and Sillince, 2007).

Reputation refers to stakeholders' perceptions of and experiences with the organisation as used to identify its unique organisational features (Deephouse and Carter, 2005). These experiences form expectations regarding the reliability of the organisation's products, its honesty, the vigour of its competitive response, and so forth. The more favourably a certain organisation and its key attributes are perceived, the more it is thought to stand out from its peers. However, in the case of new organisations, reputation judgements are more complex to form due to the lack of experience regarding the organisation's past behaviour. Stakeholders are then likely to form perceptions and judgements regarding the organisation's valuecreating potential, in terms of how the organisation is expected to perform in the future relative to other organisations in the set (Petkova, 2016). Discursively mobilised framing, then, is likely to draw from the expected reputational capital that the new organisation and interaction with it will generate for the organisation and its stakeholders. 
In a status judgement, an organisation is regarded as a member of a certain group of organisations that perform similarly regarding a set of relevant dimensions, such as quality or price, but differ from the performance of organisations in other status groups (Wejnert, 2002). The status judgement captures differences in the actors' social ranking that generate privilege or discrimination (Washington and Zajac, 2005). Accordingly, the judgement asks where the organisation fits in the ranked order of similar organisations (Bitektine, 2011, p. 163). In this case, the discursive framing is likely to strategically categorise the new organisation as part of an established organisational category that is perceived as highly valued (Delmestri and Greenwood, 2016). Even if the new organisation might lack the traditional markers of high status, discursive linkages to practices, visual materials and language use that high status actors are associated with can create such a connection.

Accordingly, dynamics of power, knowledge and ideology surround discursive processes of social judgements, emphasising the possibility of multiple accounts of social judgements that may compete with each other (Vaara et al., 2006) and evolve, develop and change across contexts. Although the construction of reputation and status, in particular, is often perceived as a positive phenomenon, all social judgement processes seek to emphasise certain qualities and attributes and marginalise others. Thus, how these social approval assets and valuecreating promises discursively emphasise or marginalise contextual factors related to space, time, practice, and change is important (Leitch and Palmer, 2010). We will now investigate why social approval assets have become an increasingly important phenomenon in the field of higher education.

\section{Higher education field transition and the competition for favourable social judgements}

Contemporary higher education has been undergoing a gradual, albeit radical, transformation across the world (Aula and Tienari, 2011; Krejsler, 2006; Siltaoja et al., 2019). As nations' economic growth and global competitiveness are increasingly driven by knowledge (Salmi, 2009), universities are expected to become more closely engaged with the business and industry sectors, and thus better able to contribute to national economies. These developments have brought to the fore the question of the fundamental meaning of a university, indicating changes in the purpose and tasks of universities as an organisational category.

The idea of the changing relationship between universities and society is often captured under the formulation of Mode 1 and 2 (Gibbons et al., 1994). This discussion is based on the arguments that the role of knowledge in society is changing, and that a new kind of knowledge creation is needed alongside the more traditional disciplinary framework (Harvey et al., 2002). Mode 1 refers to what we have traditionally understood as a scientific approach to the knowledge creation system. It is based on a clear demarcation between the public and private sectors. The role of the university was to provide discipline-based education and skills to students, and to carry out research that they believed was relevant to a particular discipline in the long run. Much of this knowledge was driven by curiosity, and produced with the intention that it would be used by other academics who also controlled the quality of knowledge. In Mode 2, distinctions between public and private knowledge creation have become blurred. Universities are increasingly involved in consultancy, and industry has become a significant participant in scientific research. Knowledge creation has shifted towards interdisciplinary research in the context of application with a focus on problemsolving, emphasising the use of collective processes of networking, negotiation, and interpersonal communication between academics and the wider public in order to tackle multiple issues (Gibbons et al., 1994; Harvey et al., 2002). 
Mode 2 is visible in the recent reconceptualisation of universities. For example, in the "entrepreneurial hotbed" conceptualisation, productive and mutually rewarding partnerships between academia and industry are developed (Styhre and Lind, 2010). Examples of entrepreneurial activities are patenting and licensing, creating incubators, science parks, and university spin-offs, and investing equity in start-ups (Rothaermel et al., 2007). Etzkowitz and Leydesdorff (1997) further use the concept of the "triple helix" to describe university-industry-government relations, and to argue that "rather than being sub-ordinated to either industry or government, the university is emerging as an influential actor and equal partner with industry and government in creating economic growth and social development" (Etzkowitz, 2003, p. 295). Universities are gradually adopting and adapting corporate management ideas and practices (Engwall, 2008), with a growing emphasis on perceiving universities as business-like actors that develop innovations and patents. This transition has also been driven by decreased university funding, enforcing an academic capitalism (Slaughter and Leslie, 2001) that seeks a transformation to integrate universities more closely with the new knowledge-based economy.

Mode 2 also places more emphasis on universities' status and reputation. The ranking, accreditation and rhetoric of "world-class" universities are increasingly important. These components are generally understood to emerge from the ideas and practices of the internationally accredited Anglo-American research-focused institutions that lead the international rankings (Slaughter and Leslie, 2001). An important element of the social evaluation of universities is that they provide status and reputation by association. Thus, being a member (an alumnus, partner, or funder) of an elite group is perceived as beneficial for the university's stakeholders and vice versa. This perception makes universities' social judgement particularly dynamic, as the institutions are expected to be judged favourably as standalone institutions but simultaneously should increase the value for and of their stakeholders. The categorisation of universities into academic and practitioner type institutions can be seen as being built on the conceptualisation of reputation as "being known for something". For example, Rindova et al. (2005) studied US business schools, suggesting that business school reputation is built on perceived quality measured by GMAT (Graduate Management Admission Test) scores, and prominence as measured by the features of media rankings, faculty publications and faculty degree prestige.

Of course, strong university names have existed for centuries, and those universities have always labelled themselves with heraldic crests, seals, and mottos. Judging them to be in the "elite category" is taken as self-evident (Aspara et al., 2014). However, universities' self- categorisation has also become common as part of "less elite" universities' efforts to influence how they are judged and perceived, because newer universities cannot draw on centuries-old status discourse (Aula and Tienari, 2011; Aula et al., 2015; Siltaoja et al., 2019). Strategically speaking, self-categorising the organisation through terminology and labels such as world-class, top-ranked and/or excellence is then expected to signal the meaning of the organisation through the expected value delivery. These labels "associate an object with a system of meaning" that is mediated through a label's denotation (or explicit meaning) and connotation (implicit meaning) (Granqvist et al., 2013, p. 396). Labels are key markers of membership in a category (Hannan et al., 2007; Slavich et al., 2020). The strategic use of labels can enable access to the resources of a category, such as funding, reputation, and status. This type of strategic categorisation process (Negro et al., 2015; Pontikes and Kim, 2017) has traditionally been perceived as a managerially planned endeavour. We argue that the process is more ambiguous and complex, and is influenced by multiple stakeholders, particularly media and contextual factors, and we elaborate on this notion through empirical data. 
The empirical focus of this study is the merger of the Helsinki University of Technology, the Helsinki School of Economics, and the University of Art and Design Helsinki into a new university, now known as Aalto University. When the merger idea was made public in 2005, universities in general were the subject of much discussion and dispute in Finland (Tirronen and Nokkala, 2009). University rectors demanded that their institutions be released from government control, which all universities were subject to, which would increase the universities' financial and operational autonomy and better enable developmental activities. The Ministry of Education [1] wanted to advance the structural development of the higher education sector, which was part of the government's productivity programme. All parties called for an operational focus for universities and clearer academic profiles.

The process was initiated in October 2006, when the Finnish Ministry of Education commissioned an inquiry into the possibilities of deepening the collaboration between the three universities mentioned above. The inquiry report (Ministry of Education, 2007) voiced concern and urgency regarding the reform of Finnish higher education, and gave instructions for establishing the new university through a merger in practice. The report exploded public debate about the rationales for the merger (Ridell, 2008). However, two months later, the establishment of the new university was written into the new government programme (Prime Minister's Office Finland, 2007). The government of Finland promised the new university a funding increase of $€ 500$ million, provided the private sector financed the endeavour with another $€ 200$ million. The new university also received larger annual funding from the state than other Finnish universities. Although the three merging universities were public and state-owned, the new university was to be governed by a private foundation, established in June 2008. The first board of Aalto University and its president were nominated later that year. The merger officially came into effect in January 2010.

\section{Research design and methodology}

This study focuses on written materials, namely accounts from reports, newspapers and the university's own stakeholder communication magazines, published before and during the merger from 2005 to 2009. Table 1 below displays the analysed materials.

The method applied is critical discourse analysis (CDA) (Fairclough, 2001) following abductive logic as the research process, emphasising a continuous interplay between theory, empirical materials and analysis. CDA focuses on the power effects that are implicit in certain texts (Fairclough, 2001). The method is highly suited to the examination of media texts and policy documents (Fairclough, 2001), enabling a longitudinal foci and examination of valuation change (Siltaoja et al., 2020). It also helps us to understand the socio political and ideological aspects of legitimacy building for organisational change (see Vaara et al., 2006). In CDA, senses of legitimacy are created in relation to discourses (Fairclough, 2001). Specific discourses give voice to particular actors, rationales, and concerns, while silencing others. Essential to CDA is a focus on the textual practices through which legitimation is carried out (Fairclough, 2001; Vaara et al., 2006). That is, certain things come to be portrayed as positive, beneficial, ethical, understandable, necessary or otherwise acceptable in the texts in question. In contrast, other things are constructed as immoral, negative, harmful, or intolerable. What is at stake in these struggles is the varying understanding of the university and its purpose, as well as its raison d'etre. While the texts seek to persuade audiences by providing an answer to the implicit question "why should we do this?", they can draw on certain legitimating accounts, such as the benefits that supporters are expected to enjoy. 
Type of text

Praised from birth

Governmental committee reports MINEDU (2007). Helsinki: Ministry of Education. Merging the Helsinki and releases

University of Technology, the Helsinki School of Economics and the University of Art and Design into a New University. No 16

Releases on http://www.minedu.fi (in Finnish only)

Other reports and brochures

Itkonen, Maija (ed.). (2009). On our way to Innovation University. The Helsinki University of Technology and The Federations of Finnish Technology Industries (2009)

New wave of know-how: Fundraising material, the Confederation of Finnish Industries (EK). 2008, 2009 (In Finnish only)

Media texts (national)

Helsingin Sanomat (HS), the major Finnish daily newspaper; texts published 6 September, 2005-31 December 2009. Kauppalehti (KL), the business daily; texts published 6 September 2005-31 December 2009. Searches conducted with the different names used for Aalto University: innovaatioyliopisto (Innovation University), huippuyliopisto (Top University), Aalto-korkeakoulu, and Aalto-yliopisto (Aalto University) Miscellaneous media texts in a range of outlets (e.g. regional newspapers, periodical magazines)

Media texts (international) Miscellaneous media texts in a range of outlets, e.g. The Financial Times, Harvard Business Review, Newsweek

Texts related to stakeholders internal to Aalto and its predecessors

Organizational Reports and

Aalto University, Towards Creativity and Innovation 2010

Brochures

Aalto University, Meillä tiede ja taide kohtaavat tekniikan ja talouden 2010

Other materials and documents

On-line and printed materials and documents on the making of a new university: communication materials, student magazine, marketing documents. 2007-2010

Accounts of the President of Aalto Oral presentations and blog entries. 2009-2010

Table 1.

Texts produced by stakeholders external

to Aalto and its predecessors

\section{Analysis process}

We conducted the analysis of the study data in four stages. In the first stage, one of the authors reviewed the materials and roughly sorted them, searching for expressions of the meaning, purpose and projected tasks of the new university. The author paid special attention to the arguments that aimed to justify the establishment of the new university, and that described the specific tasks of the new university. This analysis reduced the initially massive number of individual texts under consideration. In the second stage, the same researcher worked more closely with the selected materials, identifying a number of different meanings, roles, characteristics, and tasks for the new university that were expressed in the materials. In this initial categorisation, the focus was on the expected value of the new university, which stakeholders it served and how, and how it was ranked among similar organisations. Special attention was given to the line of argumentation and the meaning construction in each specific text by analysing wording and expression, how relationships between different actors were depicted, and where, when and by whom the text was produced and whom it targeted. As a result, two main discourses used to promote the establishment of the new university were reconstructed from the data, labelled higher education discourse and market economy discourse. Figure 1 illustrates this process.

In the third stage, we examined how particular conceptions of the new university and its meaning were discursively constructed and legitimated in these two discourses. 
BJM

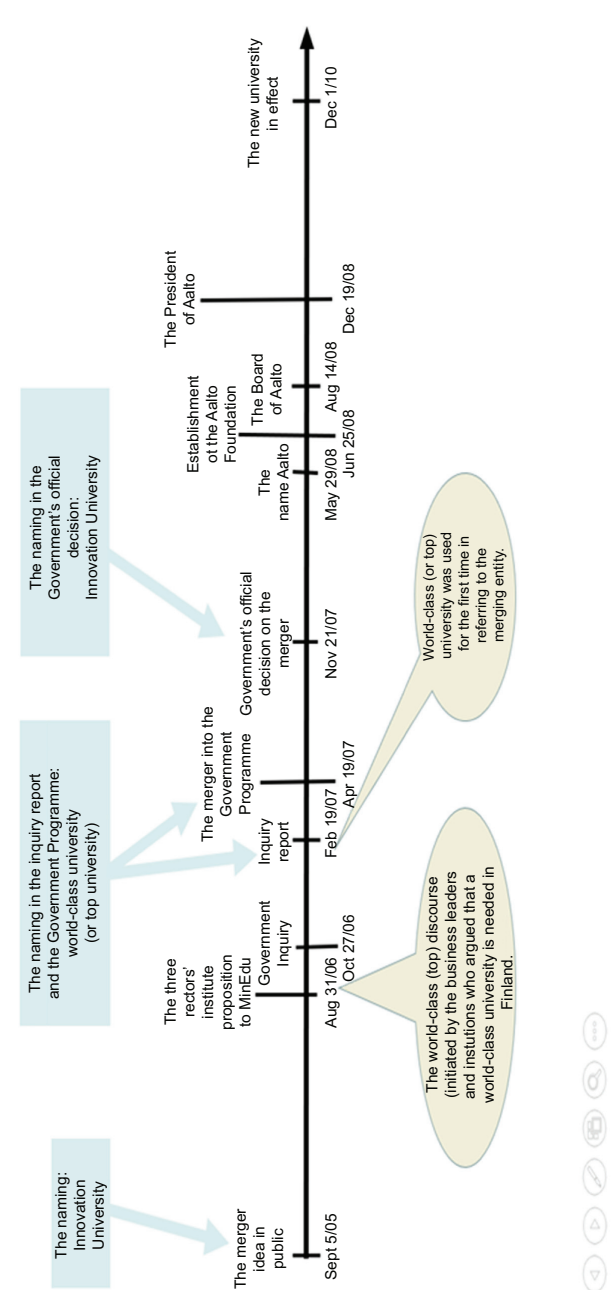

Figure 1.

Timeline of main events and decisions regarding the

establishment of Aalto University

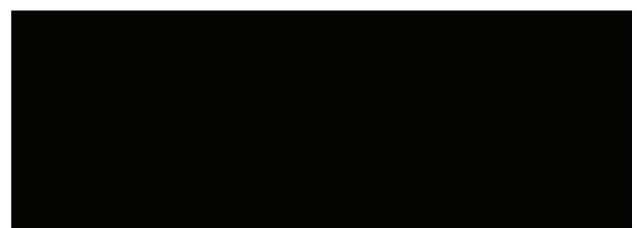


Different constructions of the new university became specifically salient in what the new university was called before it received its official name, that of Aalto University. This observation allowed us to examine what meanings the labels "Innovation University" and "Top University" gave to the new university in the two discourses. We then analysed the mobilisation of the names in all the materials. We illustrate this change in Figure 2 through a systematic analysis of Helsingin Sanomat (HS), the daily newspaper with the widest national circulation in Finland, as our data from that newspaper cover all of the articles that mentioned the merger over the entire time-frame of the study.

Both discourses provided a new Mode 2 basis for universities, but from different angles. In the higher education discourse, the new university was contextualised within (Finnish) higher education. Expressions such as "higher education reform" and "implemented by the Ministry of Education" placed the new university in the structural development of Finnish universities led by the Ministry of Education in Finland. The new university was constructed as a flagship project in the reform of the sector towards interdisciplinary, world-class science. In the market economy discourse, the new university was contextualised in association with the current and future state of the Finnish economy. References to "competence capital" and "the competitiveness of the Finnish business community" constructed the purpose of the university to secure the well-being of Finnish society and business life.

We then examined how these two discourses legitimised the new university in such a way so as to fit current societal needs and expected values (reputation and status). This investigation was a constant process of iteration, going back and forth with the data based on discussions with the authors. The key findings are summarised in Table 2 , and the empirical results are discussed thereafter.

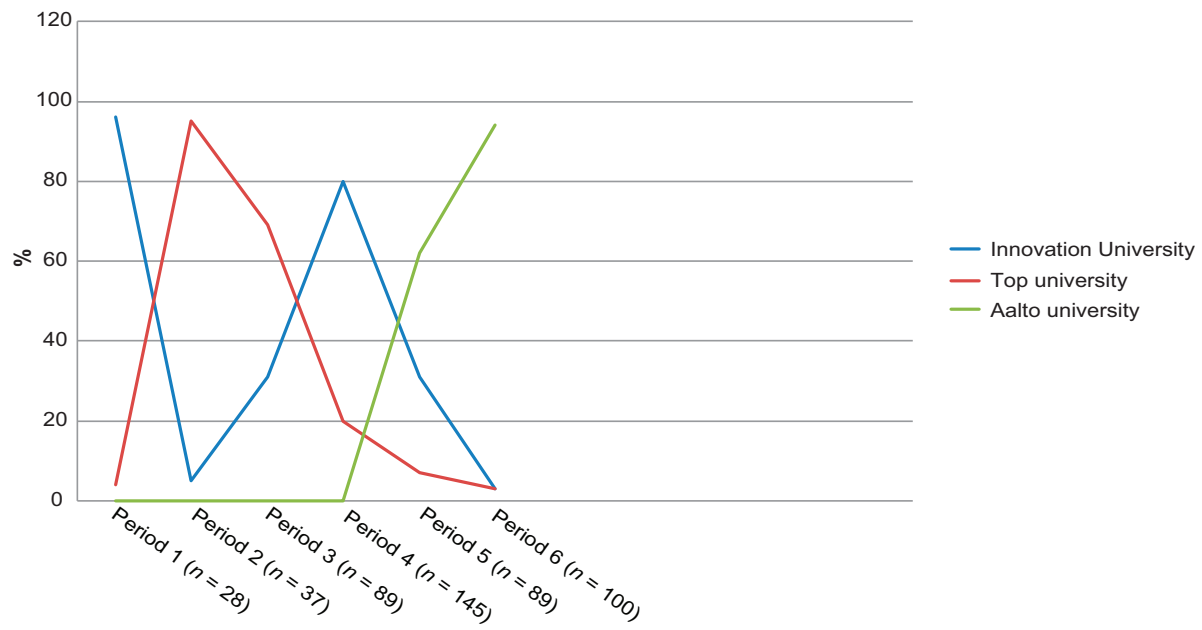

Note(s): The \% illustrates the use of names in articles in refers to articles per period. The periods are as follows (following the timeline regarding major decisions in Figure 1): Period 1: Sep 5, 2005- Feb 18, 2007; Period 2: Feb 19, 2007 - Apr 18, 2007; Period 3: Apr 19, 2007 -Nov 21, 2007; Period 4: Nov 22, 2007 - May 28, 2008; Period 6: Dec 21, 2008 - Dec 31, 2009
Praised from birth 


\begin{tabular}{|c|c|c|}
\hline & Higher education discourse & Market economy discourse \\
\hline $\begin{array}{l}\text { Purpose of the new } \\
\text { university }\end{array}$ & $\begin{array}{l}\text { To advance the Finnish higher education } \\
\text { sector reform } \\
\text { To advance the international standing of } \\
\text { Finnish higher education }\end{array}$ & $\begin{array}{l}\text { To secure and advance the wellbeing o } \\
\text { Finnish business life and society } \\
\text { To advance the national innovation } \\
\text { policy }\end{array}$ \\
\hline $\begin{array}{l}\text { The nature of the } \\
\text { new university }\end{array}$ & $\begin{array}{l}\text { A multidisciplinary university } \\
\text { Focus on the areas in which Aalto is already } \\
\text { strong and has the status of being as close to } \\
\text { "world-class" as possible }\end{array}$ & $\begin{array}{l}\text { A triple helix model university } \\
\text { Focus on areas that are important to } \\
\text { Finland and the Finnish economy, } \\
\text { increasing the expected value of } \\
\text { excellence, namely the reputation of } \\
\text { Finland, Finnish businesses, and the } \\
\text { New University itself }\end{array}$ \\
\hline $\begin{array}{l}\text { Academic } \\
\text { functions of the } \\
\text { new university }\end{array}$ & Research and teaching & $\begin{array}{l}\text { Research, teaching, and economic } \\
\text { development }\end{array}$ \\
\hline
\end{tabular}

\section{Results}

\section{The higher education discourse}

The higher education discourse was specifically about legitimation through expected status benefits for Finland, and was developed in relation to the discussion about the structural developments of the Finnish higher education sector. The discourse depicted a situation in which Finnish higher education was lagging behind on a global level, and that the reasons for this lay in operational preconditions such as insufficient funding and tight government control, which restricted organisational autonomy in financial, management and personnel issues. In addition, a low degree of internationalisation, a high student to professor ratio, and the common practice of greatly extending the length of studies towards a degree were often brought up as drawbacks of Finnish universities. These problems and challenges were broadly discussed and were a concern for all Finnish universities. References were often vaguely made to systems in other countries, without addressing the comparability of the educational systems:

Increasingly, Finnish universities are competing in the international market for finance and talent. The fact is that Finnish universities lag behind European and American universities in their facilities... . The current reform process must not forget its basic aim, which is to create an up-to-date operating environment for Finnish universities, to enable them to better fulfil traditional academic responsibilities - research and teaching - the very heart and soul of academia [2].

The new university was constructed as the spearhead project of Finnish university reform, an experiment whose results could then be used in other Finnish universities [3]. The Ministry of Education (2007, p. 37) attempted to legitimise the new university's position as the most important individual project in the reform effort as follows: "quick and extensive reform is more likely to be achieved when reform focuses on a limited number of universities".

However, the formation of the new university was contested, particularly by other higher education representatives. The rector of the University of Helsinki wrote a letter to the editor of HS (7 February 2008) arguing that it was not the creation of a new university that would solve the sector's low status problems but the reforms contained in the New Universities Act (which was eventually passed in the Finnish Parliament in 2009):

Obviously, major stumbling blocks for the global success of Finnish universities are, on the one hand, their official status as public sector institutions, with public sector financial accountability, and on the other hand, their dated management and decision making styles. Luckily, the current reform process, to which the government is committed, will change this situation for all Finnish universities. 
While the current challenges in the sector were presented as common to all universities, the developments were presented as university specific. At the same time, the new university was positioned in the same group as "modern European and American universities" (HS, 22 December 2007). This status-seeking goal of the new university was particularly enforced through the positioning of the university as a world-class university in specific areas that were later defined in the research assessment exercise (RAE). The RAE was one of the first projects the newly nominated board initiated in 2009. In the communication materials (29 October 2008), the chair of the Aalto University board argued that the RAE was "crucial for our efforts to create a world class Aalto University". Thus, the claim was made that the new university would immediately be judged as prestigious and placed in the top ranks.

\section{The market economy discourse}

In the market economy discourse, the legitimation process for the new university relied on the triple helix view, and was constructed in relation to the competitiveness of the Finnish economy and business sector. The discourse relied on an argument, particularly on behalf of business and technology representatives, that the existing universities were not beneficial for business development and had a bad reputation for not delivering valued products. The suggested solution was the establishment of a new university that would deliver the expected stakeholder value.

Although different economic indicators suggested that the technology sector was doing well [4], industry representatives insisted that Finnish technological know-how was lagging behind international development [5] and that Finland was losing its attractiveness to international investors [6]. In addition, the quality of teaching at existing universities was questioned; the insufficient know-how of Finnish university graduates was presented as a reason for the negative prospects of the Finnish technology sector:

The Managing Director of Finnish Technology Industries is worried that Finnish technological knowhow is coming to a standstill. He argues that the level of higher education teaching and research in technology is now unforgivably low, and is already reducing the attractiveness of investments in Finland [7].

The technology sector saw the innovative aspect of the Aalto University trio of technology, business, and design as particularly beneficial. After the inquiry report (Ministry of Education, 2007), and just before the new university was included in the government programme (Prime Minister's Office Finland, 2007), the Federation of Finnish Technology Industries promised to provide $€ 80$ million for the new university [8], which amounted to $40 \%$ of the required private funding that would then secure the additional $€ 500$ million from the federal government.

In the promoted Mode 2 view, the value of the new university lay in its new academic function: instead of providing only research and teaching, the new university was presented as an answer to the challenges facing not only the technology sector, but also the whole Finnish economy. The argument was that "Technology industries are vital for Finnish welfare, and their future depends on the competitiveness of Finnish universities" [9]. Thus, the new university became an important part of the Finnish government's innovation policy. The rector of the design school, who first suggested the establishment of the new university, later explained that his suggestion was aligned with the idea of developing the Finnish innovation system "to create multidisciplinary environments that would fuel innovation, improve the commercial exploitation of research results, and, overall, make our innovation processes more efficient" [10]. The venture was then recognised internationally when the Harvard Business Review (March 2009) published an article titled "Tapping the World's Innovation Hot Spots", which presented several nation-specific variants of innovation 
strategy, including Aalto University, which was labelled as "one of the best examples of Finland's large-scale, holistic approach to innovation".

Supporters insisted that the Mode 2 view of the university would entail significant national advantages. The discourse portrayed how the new university would (re)brand Finland as a leading technology and entrepreneur-friendly country, aiming to attract new investment in Finland. The recent financial crises, and particularly the decline of Nokia Corporation, were used to contextualise the need for a new era. The new university was expected to focus on new business development, which was seen as important to Finland and the Finnish economy. Concrete suggestions included the following:

[ . . ]Top class technological knowhow, business knowhow, innovations in, and enhancement of, the service sector, more innovative operational models, strategic management and continuing strategic reform in companies, together with industrial design [11].

Interestingly, although in the higher education discourse the focus areas were defined according to the existing strengths of the universities, the market economy discourse emphasised change and focused on specific areas considered to be important to Finnish society and business life.

\section{What's in a name? The higher education discourse and the labelling of the new university} In the early phase, the new university was labelled as Innovation University (Innovaatioyliopisto) and Top University (Huippuyliopisto) before it received its official name, Aalto University, in 2008. The whole idea of the Aalto University merger was publicly launched in 2005 in the following way:

From the perspective of national welfare and the nation's future - a greater benefit would be obtained from the creation of a completely new university formed from the University of Art and Design, the University of Technology, and the Helsinki School of Economics. From an international perspective, the profile of this kind of an "innovation university" would be unique; from the Finnish perspective, it would be the country's second biggest university as far as student numbers are concerned. If the creation of this university were not to start from an administrative point of view but from a genuine effort to create a new university that would stress new kinds of innovation; if this new university was to have considerable autonomy, innovate new types of collaboration with business and industry and receive substantially larger funding - then we would be able to create an environment with the potential to develop world class knowledge and knowhow. We should promote the development of such a high profile project.

In the opening speech for the new academic year 2006, the rector of the University of Art and Design Helsinki envisioned a new university, labelling it Innovation University [12]. The next morning, the rector was quoted in the biggest Finnish daily paper (HS, 5 September 2006) as saying: "We need a creative union of design, technology, and marketing - a true innovation university". Representatives of the business community and other actors then used the term, and it became the name generally used to refer to the new university.

In 2007, the inquiry report (Ministry of Education, 2007) dismissed the name Innovation University (referring to the expected value derived from knowledge creation) and instead used the name Top University (referring to its relative position in the network of universities). Both names were used until the official name, Aalto University, was introduced in 2008. In the higher education discourse the new university itself was labelled an innovation - a novel organisation in Finnish higher education. Arguments about the uniqueness of the new university referred to the combination of the three fields of the merging schools: technology, business, and art and design. "This combination has attracted global interest, as there do not seem to be many like it", argued the representative of the Ministry of Education [13]. This interdisciplinarity was characterised in various ways: a marriage of science and art [14], 
a combination of technology, design and art [15], and a combination of technology, design and marketing [16].

The label Top University took centre stage from 2007 onward. In the higher education discourse, top came to refer to academic research excellence and global university rankings. Top implied that Aalto University would immediately be categorised among the elite research universities in the world; the new university was systematically benchmarked against world-famous academic institutions such as the Massachusetts Institute of Technology and Stanford.

While Finnish universities had earlier been accused of being low level performers, the three merging universities were suddenly represented in a very positive light even individually, which was in sharp contrast to previous public discussion and the mud-slinging aimed at Finnish universities. The three merging schools were praised as "nationally appreciated and high-quality universities which have also reached an international top-level in certain specific areas" [17]. Even before external evaluations took place, Aalto University utilised this "world-class" rhetoric in its own materials from 2009 onward.

However, this world-class rhetoric was also belittled and ridiculed, as it was widely recognised that an institution does not become world-class or a member of this exclusive category of world-class universities simply by self-declaration. Moreover, labelling one university as "the top" made all other universities seem to be innately lower status. Professors at the University of Helsinki, the highest-ranked university in Finland (in the Academic Ranking of World Universities), pointed out that "there already is an international university in Finland, it is called the University of Helsinki" [18], and "a top-university has existed in Finland for 367 years!" [19]. Over time, the top university expression started to attract less attention in the media. In a way, it did not succeed in making the new university distinct enough from the existing universities and so became used less frequently, as shown in Figure 2.

The Innovation University and Aalto University labels benchmarked interdisciplinarity, presented as the novel and unique characteristic of Aalto University in Finnish higher education. As interdisciplinarity stood for "doing things differently", Aalto University's materials presented various student projects in which creative and innovative working practices had been applied. In research, interdisciplinarity was typically referred to with the term multidisciplinarity, and was manifested in research projects that "[bring] together researchers from all three of Aalto University's main schools" [20].

To sum up, world-class multidisciplinary research became a key organisational characteristic in building Aalto University's legitimacy. The higher education discourse then categorised the organisation as interdisciplinary, but also as having world-class disciplinary specialisation. Thus, the rhetoric used in association with Aalto University simultaneously drew on its expected excellent research reputation and prestigious status.

\section{What's in a name? The innovation university label in the market economy discourse}

In the market economy discourse, the name Innovation University referred to the task of the new university to create something new (innovations) that would have commercial value. Described as an "integrated seedbed for innovation" [21] "exploring novel, commercially significant ideas" [22], the new university was seen as tasked with "spur[ring] innovation" [23] and encouraging new types of knowledge creation and innovation.

The name Top University began to refer to (graduate) students' skills and know-how, and to the quality of the university-business research collaboration. The former meant that the new university should educate skilful employees for the needs of global businesses and train start-up entrepreneurs [24]. Such research collaboration was claimed to provide a way to reconstruct Finland's reputation as a leading high-technology country. 
The communication materials begun to address the value of the new university through entrepreneurial initiatives and a number of partnerships with leading corporations, such as Microsoft and Nokia. This strengthened the university's expected role in supporting Finland's innovation strategy, and in branding Finland as a leading technology country through research and teaching that would be relevant to practice. The main daily Finnish business paper, Kauppalehti (29 September 2006), published an article in which the vice chief executive officer (CEO) of Nokia was interviewed. The text stated:

According to [the vice CEO], art and design create precisely the sort of products that people will want to buy in the future. People want goods to be replaced by entertainment, formats, images and sound. "There is not enough education in art and design, and what there is, is incorrectly focused. The emphasis must be on the production of digital experiences," says [the vice CEO]. He [the vice CEO] then took up the innovation university that Finland is planning, which unfortunately is threatened with failure due to petty internal squabbling. "Completely inconceivable," he said. "The project is an example of the visionary new thinking that is now needed."

This practice- and business-oriented task assigned to the new university had indeed become the subject of negotiation and contestation. HS published an editorial (15 March 2008) in which the tasks of Finnish universities were divided into four categories. One of the tasks (supporting innovation) was indicated as belonging to the new university, while the other three tasks (international top-level research, education, and advancement of stable regional development) were allocated to other Finnish universities. Thus, universities were categorised differently regarding their anticipated capability. In addition, such categorisation implied that attracting resources for one top university "is far more important than providing equal resources for all Finnish universities so that they can compete amongst themselves" [25].

Such market privilege, however, was considered incompatible with Finnish traditions that emphasised equality and results-based rewards. The issue was brought up in public discussion. "American - but not a dream" was a sarcastic heading in Aino, the Aalto University Student Union magazine (29 September 2009). Moreover, the legal status of the new university as a foundation was considered as difficult to integrate with the traditions of Finnish universities and their collegial decision-making. In particular, the market-oriented goal raised strong resistance in one of the merging schools, the School of Art and Design Helsinki. The school's personnel and students organised demonstrations against the new university, and along with representatives of the culture sector in Finland published a plea signed by more than 5,000 persons. The plea demanded that the school should not become part of the new university, because not everything can be measured and evaluated by the criteria of economic development. Despite such challenges posed by these market-oriented goals, the merger proceeded as planned.

To sum up, the new university was constructed as having high value-creation potential regarding technology, product and service development, support for start-ups, and the creation of a new kind of ecosystem in Finland. In practice, this also entailed the legitimisation of academic capitalism (Slaughter and Leslie, 2001) in Finland, due to the emphasis on research on applications, the commercialisation of research results, the acquisition of international patents, and the promotion of education for entrepreneurship (Kauppinen and Kaidesoja, 2014).

\section{Discussion and conclusions}

In this study, we have explored how different labels and claims of stakeholder benefits were discursively constructed and used in the legitimation of a new higher education organisation. The findings suggest that the new university was legitimated through two main discourses: 
higher education and market economy. These discourses were promoted by elite actors in academia, political spheres and in the business world. Although the proponents faced a great deal of resistance, the merger proceeded as planned. The actors not only sought to justify the new university as being categorically different from existing Finnish universities, but did so by rationalising the merger (see, e.g. Vaara et al., 2006). In addition, the new university was legitimated by using the expected status and reputation benefits that were claimed would entail to the benefit of its supporters. As a result, the organisation gained its legitimacy, enforced by the legislative change - university reform - which enforced Mode 2 thinking regarding the role of universities in Finland. We will now discuss our contributions regarding the role of social approval assets and different labels in the legitimation of new higher education organisations.

First, our study showed how status and reputation are discursive materials used to disseminate and justify new interests, norms, structures and values in a stakeholder network, offering positive and aspirational future scenarios in the context in which they emerge. The discursive legitimation of Aalto University was not only about the favourable judgement of the new organisation, but also relied on rationalising claims (value propositions) of improved status and reputation for its stakeholders. In particular, even though Finland is at the top of international rankings in primary school education (measured, for example, by the Programme for International Student Assessment [PISA] and also global rankings measuring countries' technological development and innovation capability, no Finnish university had been ranked among the most prestigious (e.g. the top 50) universities globally. This reputation void was a discursive resource for the establishment and legitimation of the new university. It was backed up by high-status actors such as famous CEOs (see also Rao et al., 2003), and legitimating bodies such as the Ministry of Education (see also Ruef and Scott, 1998), by directing attention to particular offerings of the new organisation that existing universities could not provide (see Zuckerman, 1999).

This finding contributes to the nascent literature on social approval assets from the discursive and critical perspectives (Lähdesmäki and Siltaoja, 2010; Siltaoja et al., 2020; Suddaby and Greenwood, 2005; Vaara and Monin, 2010; Vaara et al., 2006). This stream of studies has argued that social approval assets are discursive materials that are continuously (re)constructed in social processes. We add to the literature by showing how social approval assets are a type of power-play, discursive capital for stakeholders, used to promote or resist changes in the existing power hierarchy. Accordingly, rather than having a narrow focus on whether an organisation is perceived to have a reputation, status, or legitimacy that is good or bad (or high or low), we encourage a focus on the multiple processes that make up these constructions, who benefits from the production and mobilisation of (un)favourable evaluations, and in what material and structural effects these constructions are embedded.

Our second contribution elaborates on the use of labels in the strategic categorisation processes of a new organisation resulting from a merger. The strategic categorisation process is generally perceived as a managerial endeavour, a process in which managers "hedge their bets" (Granqvist et al., 2013) and seek to strategically align their organisation in the best possible organisational category or categories (Pontikes and Kim, 2017). Our study shows how this is not merely a managerial endeavour; a strategic categorisation process can involve multiple stakeholders and types of stakeholder work. For example, in this study, the labels used to categorise the new university (Top University and Innovation University) were highly influenced by the media, as embedded in the wider political and societal circles of Finland. Interestingly, the use of multiple labels (names) is traditionally perceived as a negative phenomenon for legitimacy (Hannan et al., 2007). However, Slavich et al. (2020) suggested that multiple labels allow actors and audiences that do not necessarily have the same understanding of the category or shared interests to participate in the process. Labels are not merely names and signals; we find that labels invoke specific purposes (Kodeih et al., 2019), connect to 
ideological struggles (Siltaoja et al., 2020), and can be read as signals of wider societal transformations. The construction of meaning in the examined case was a process of political contestation and the manipulation of cultural symbols and norms for what universities are about and what they should signify. Furthermore, in the examined case, the labels targeted both the expected reputation and status benefits (world-class university) and culturally valued attributes (innovation). Thus, we suggest that the strategic categorisation of emerging organisations can benefit from combining culturally valued attributes with anticipated changes (see also Siltaoja et al., 2020).

For practical relevance, this study shows the role of media and labels in designing change, and how policy enforcement can take place in arenas that are not necessarily perceived as policymaking. For example, the establishment of Aalto University was not only about that particular organisation, but also challenged the legitimacy of an existing and well-established system (universities in the country) and initiated a wide-scale reform, paving the way for the new Mode 2 conceptualisation of universities in Finland.

For managers, it is crucial to understand how a chosen label can result in both stakeholder support and resistance, and how important it is to anticipate the changes a label can invoke. Even though managers might label their products and organisations in certain ways, the media and stakeholders can associate confusing meanings with these labels (see also Siltaoja et al.,2020). Thus, it is crucial to read the subtle signs across various media when hedging bets using various labels.

Our study further offers possibilities to study category demise. For example, the world-class discourse has spread to almost all Finnish universities, alongside the Mode 2 type of thinking, in more mature and nascent forms. There are possibilities for theory development on how the absence of language (silence) may hasten the demise of a more traditional conception of a university, as well as how the production of temporalised discourses about an old-fashioned category can indicate such a demise (see Granqvist and Siltaoja, 2020). For example, this is quite apparent when we consider the silence regarding the Humboldtian model for universities in an academic setting (Alajoutsijärvi et al., 2013).

Our study naturally has limitations. Although the use of one or a few cases is generally considered sufficient to produce useful insights, our findings may feature moderate generality (see Langley, 1999). Furthermore, the case took place in a societal context where public universities are the norm. This has likely influenced the content of discussion, the way social approval assets were mobilised, and how the discourses addressed change.

\section{Notes}

1. The name of the ministry changed during the study period. The Ministry of Education became the Ministry of Education and Culture in May 2010. See more at http://www.minedu.fi/OPM/Tiedotteet/ 2010/04/nimenmuutos.html?lang=fi. For clarity, we use the name "the Ministry of Education" throughout this paper.

2. Helsingin Sanomat, 22 December 2007.

3. MINEDU (2007).

4. Kauppalehti, 28 July 2006.

5. Helsingin Sanomat, 14 October 2006.

6. Helsingin Sanomat, 5 May 2006.

7. Kauppalehti, 28 July 2006.

8. Helsingin Sanomat, 30 March 2007.

9. Helsingin Sanomat, 14 October 2006. 
10. Helsingin Sanomat, 15 February 2006.

11. MINEDU (2007).

12. The Finnish word innovaatioyliopisto has been translated into English in two ways: Innovative and Innovation University. The two translations may have different meanings for the university. In Finnish, only the word innovaatioyliopisto was used to refer to the new university.

13. Helsingin Sanomat, 14 May 2008.

14. Available at: http://www.aaltoyliopisto.info/en/view/innovaatioyliopisto-info/the-name (accessed 20 November 2009).

15. President of Aalto University's speech at Aalto University's public opening ceremony in 2010.

16. Helsingin Sanomat, Koulutusliite, 2009.

17. $\operatorname{MINEDU}(2007$, p. 38).

18. Helsingin Sanomat, 27 March 2007.

19. Helsingin Sanomat, 9 September 2007.

20. Aalto University promotional materials: towards creativity and innovativeness. 2010.

21. Financial Times, March 2009. Available at: http://www.ft.com/cms/s/2/5399caa8-1aeb-11de-8aa30000779fd2ac,dwp_uuid=02e16f4a-46f9-11da-b8e5-00000e2511c8.html (accessed 21 April 2009).

22. Harvard Business Review, March 2009.

23. Game Theory: Go Global or Go Home, The Globe and Mail, 8 September 2011.

24. http://publicservice.co.uk/ Economic growth - an opportunity for improvement; 16 January 2012 (accessed 23 January 2012).

25. Helsingin Sanomat, 14 October 2006/letter to the editor by the president of the Confederation of Finnish Industries (EK), published on the editorial page.

\section{References}

Alajoutsijärvi, K., Juusola, K. and Siltaoja, M. (2013), "Academic capitalism hits the fan: the birth of acamanic capitalism", in Malin, V., Murphy, J. and Siltaoja, M. (Eds), Dialogues in Critical Management Studies. Getting Things Done, Emerald Group Publishing, Vol. 2, pp. 91-121.

Aspara, J., Aula, H.-M., Tienari, J. and Tikkanen, H. (2014), "Struggles in organizational attempts to adopt new branding logics: the case of a marketizing university", Consumption, Markets and Culture, Vol. 17 No. 6, pp. 522-552.

Aula, H.-M. and Tienari, J. (2011), "Becoming 'world-class?' Reputation-building in a university merger", Critical Perspectives on International Business, Vol. 7 No. 1, pp. 7-29.

Aula, H.-M., Tienari, J. and Wæraas, A. (2015), "The university branding game: players, interests, politics", International Studies of Management and Organization, Vol. 45 No. 2, pp. 164-179.

Bitektine, A. (2011), "Toward a theory of social judgments of organizations: the case of legitimacy, reputation, and status", Academy of Management Review, Vol. 36 No. 1, pp. 151-179.

Deephouse, D.L. and Carter, S.M. (2005), "An examination of differences between organizational legitimacy and organizational reputation", Journal of Management Studies, Vol. 42 No. 2, pp. 329-360.

Deephouse, D.L. and Suchman, M. (2008), "Legitimacy in organizational institutionalism", in Greenwood, R., Oliver, C., Suddaby, R. and Sahlin, K. (Eds), The Sage Handbook of Organizational Institutionalism, Sage, Thousand Oaks, CA, pp. 49-77.

Delmestri, G. and Greenwood, R. (2016), "How Cinderella became a queen: theorizing radical status change", Administrative Science Quarterly, Vol. 61 No. 4, pp. 507-550. 
Engwall, L. (2008), “The university: a multinational corporation?”, in Engwall, L. and Weaire, D. (Eds), The University in the Market, Portland Press, London, pp. 9-21.

Etzkowitz, H. (2003), "The European entrepreneurial university: an alternative to the US model", Industry and Higher Education, Vol. 17 No. 5, pp. 325-335.

Etzkowitz, H. and Leydesdorff, L. (1997), "Introduction to special issue on science policy dimensions of the triple helix of university-industry-government relations", Science and Public Policy, Vol. 24 No. 1, pp. 2-5.

Fairclough, N. (2001), Language and Power, 2nd ed., Longman, London.

Fombrun, C. and Van Riel, C. (1997), "The reputational landscape", Corporate Reputation Review, Vol. 1 Nos 1-2, pp. 5-13.

Gibbons, M., Limoges, C., Schwartzman, S., Nowotny, H., Trow, M. and Scott, P. (Eds) (1994), The New Production of Knowledge, Sage, London.

Golant, B.D. and Sillince, J.A. (2007), "The constitution of organizational legitimacy: a narrative perspective”, Organization Studies, Vol. 28 No. 8, pp. 1149-1167.

Granqvist, N. and Gustafsson, R. (2016), "Temporal institutional work", Academy of Management Journal, Vol. 59 No. 3, pp. 1009-1035.

Granqvist, N. and Siltaoja, M. (2020), "Constructions, claims, resonance, reflexivity: language and market categorization", Organization Theory, Vol. 1 No. 4, pp. 1-32.

Granqvist, N., Grodal, S. and Woolley, J.L. (2013), "Hedging your bets: explaining executives' market labeling strategies in nanotechnology", Organization Science, Vol. 24 No. 2, pp. 395-413.

Hannan, M.T., Hannan, M.T., Pólos, L. and Carroll, G.R. (2007), Logics of Organization Theory: Audiences, Codes, and Ecologies, Princeton University Press, New Jersey.

Harvey, J., Pettigrew, A. and Ferlie, E. (2002), "The determinants of research group performance: towards mode 2?", Journal of Management Studies, Vol. 39 No. 6, pp. 747-774.

Hubbard, T.D., Pollock, T., Pfarrer, M. and Rindova, V. (2017), "Safe bets or hot hands? How status and celebrity influence strategic alliance formations by newly-public firms", Academy of Management Journal, Vol. 61 No. 5, doi: 10.5465/amj.2016.0438.

Kauppinen, I. and Kaidesoja, T. (2014), "A shift towards academic capitalism in Finland”, Higher Education Policy, Vol. 27 No. 1, pp. 23-41.

Kodeih, F., Bouchikhi, H. and Gauthier, V. (2019), “Competing through categorization: product- and audience-centric strategies in an evolving categorical structure", Organization Studies, Vol. 40 No. 7, pp. 995-1023.

Krejsler, J. (2006), "Discursive battles about the meaning of university: the case of the Danish university reform and its academics", European Educational Research Journal, Vol. 5 Nos 3-4, pp. 210-220.

Lähdesmäki, M. and Siltaoja, M. (2010), "Towards a variety of meanings - multiple representations of reputation in the small business context”, British Journal of Management, Vol. 21 No. 1, pp. 207-222.

Langley, A. (1999), "Strategies for theorizing from process data", Academy of Management Review, Vol. 24 No. 4, pp. 691-710.

Leitch, S. and Palmer, I. (2010), "Analysing texts in context: current practices and new protocols for critical discourse analysis in organization studies”, Journal of Management Studies, Vol. 47 No. 6, pp. 1194-1212.

Ministry of Education (2007), Merging the Helsinki University of Technology, the Helsinki School of Economics and the University of Art and Design into a New University, Ministry of Education, Helsinki.

Negro, G., Hannan, M.T. and Fassiotto, M. (2015), “Category signaling and reputation”, Organization Science, Vol. 26 No. 2, pp. 584-600. 
Petkova, A. (2016), "Standing out or blending in? The formation of new firms' legitimacy and reputation under different levels of market uncertainty", Corporate Reputation Review, Vol. 19 No. 1, pp. 22-34.

Pfarrer, M.D., Pollock, T.G. and Rindova, V.P. (2010), "A tale of two assets: the effects of firm reputation and celebrity on earnings surprises and investors' reactions", Academy of Management Journal, Vol. 53 No. 5, pp. 1131-1152.

Pontikes, E.G. and Kim, R. (2017), "Strategic categorization", in Durand, R., Granqvist, N. and Tyllström, A. (Eds), From Categories to Categorization: Studies in Sociology, Organizations and Strategy at the Crossroads, Emerald Publishing, New Jersey, pp. 71-111.

Prime Minister's Office Finland (2007), “Government programme of prime minister Matti Vanhanen's second cabinet", available at: https://valtioneuvosto.fi///69-paaministeri-matti-vanhasen-iihallituksen-ohjelma (accessed 7 January 2021).

Rao, H., Monin, P. and Durand, R. (2003), "Institutional change in Toque Ville: nouvelle cuisine as an identity movement in French gastronomy", American Journal of Sociology, Vol. 108 No. 4, pp. 795-843.

Ridell, S. (2008), "Top university - downhill for humanities? Policing the future of higher education in the Finnish mainstream media”, European Educational Research Journal, Vol. 7 No. 3, pp. 289-307.

Rindova, V.P. and Fombrun, C. (1999), "Constructing competitive advantage: the role of firmconstituent interactions", Strategic Management Journal, Vol. 20, pp. 691-710.

Rindova, V.P., Williamson, I.O., Petkova, A.P. and Sever, J.M. (2005), "Being good or being known: an empirical examination of the dimensions, antecedents, and consequences of organizational reputation", Academy of Management Journal, Vol. 48 No. 6, pp. 1033-1049.

Rothaermel, F.T., Agung, S.D. and Jiang, L. (2007), "University entrepreneurship: a taxonomy of the literature", Industrial and Corporate Change, Vol. 16 No. 4, pp. 691-791.

Ruef, M. and Scott, W.R. (1998), "A multidimensional model of organizational legitimacy: hospital survival in changing institutional environments", Administrative Science Quarterly, Vol. 43, pp. 877-904.

Salmi, J. (2009), "The challenge of establishing world-class universities", available at: https://www. researchgate.net/publication/44840421_The_Challenge_of_Establishing_World-Class_ Universities (accessed 7 January 2021).

Sauermann, H. and Stephan, P. (2013), "Conflicting logics? A multidimensional view of industrial and academic science”, Organization Science, Vol. 24 No. 3, pp. 889-909.

Siltaoja, M.E. and Vehkaperä, M.J. (2010), "Constructing illegitimacy? Cartels and cartel agreements in Finnish business media from critical discursive perspective", Journal of Business Ethics, Vol. 92 No. 4, pp. 493-511.

Siltaoja, M., Juusola, K. and Kivijärvi, M. (2019), “World-class' fantasies: a neocolonial analysis of international branch campuses”, Organization, Vol. 26 No. 1, pp. 75-97.

Siltaoja, M., Lahdesmaki, M., Granqvist, N., Kurki, S., Puska, P. and Luomala, H. (2020), "The dynamics of (de)stigmatisation: boundary construction in the nascent category of organic farming", Organization Studies, Vol. 41 No. 7, pp. 993-1018.

Slaughter, S. and Leslie, L.L. (2001), "Expanding and elaborating the concept of academic capitalism", Organization, Vol. 8 No. 2, pp. 154-161.

Slavich, B., Svejenova, S., Opazo, M.P. and Patriotta, G. (2020), "Politics of meaning in categorizing innovation: how chefs advanced molecular gastronomy by resisting the label", Organization Studies, Vol. 41 No. 2, pp. 267-290.

Styhre, A. and Lind, F. (2010), "The softening bureaucracy: accommodating new research opportunities in the entrepreneurial university", Scandinavian Journal of Management, Vol. 26 No. 2, pp. 107-120. 
Suddaby, R. and Greenwood, R. (2005), "Rhetorical strategies of legitimacy", Administrative Science Quarterly, Vol. 5 No. 1, pp. 35-67.

Tirronen, J. and Nokkala, T. (2009), "Structural development of Finnish universities: achieving competitiveness and academic excellence", Higher Education Quarterly, Vol. 63 No. 3, pp. 219-236.

Vaara, E. and Monin, P. (2010), "A recursive perspective on discursive legitimation and organizational action in mergers and acquisitions", Organization Science, Vol. 21 No. 1, pp. 3-22.

Vaara, E., Tienari, J. and Laurila, J. (2006), "Pulp and paper fiction: on the discursive legitimation of global industrial restructuring", Organization Studies, Vol. 27 No. 6, pp. 789-813.

Washington, M. and Zajac, E.J. (2005), "Status evolution and competition: theory and evidence", Academy of Management Journal, Vol. 48 No. 2, pp. 282-296.

Wedlin, L. (2008), "University marketization: the process and its limits", in Engwall, L. and Weaire, D. (Eds), The University in the Market, Portland Press, London, pp. 143-153.

Wejnert, B. (2002), "Integrating models of diffusion of innovations: a conceptual framework", Annual Review of Sociology, Vol. 28, pp. 297-326.

Zhao, E.Y., Ishihara, M. and Lounsbury, M. (2013), "Overcoming the illegitimacy discount: cultural entrepreneurship in the US feature film industry", Organization Studies, Vol. 34 No. 12, pp. $1747-1776$.

Zuckerman, E.W. (1999), "The categorical imperative: securities analysts and the illegitimacy discount", American Journal of Sociology, Vol. 104 No. 5, pp. 1398-1438.

\section{Corresponding author}

Marjo Siltaoja can be contacted at: marjo.siltaoja@jyu.fi

For instructions on how to order reprints of this article, please visit our website:

www.emeraldgrouppublishing.com/licensing/reprints.htm

Or contact us for further details: permissions@emeraldinsight.com 